\title{
The use of micro-level discourse markers in British and American feature- length films: Implications for teaching in EFL contexts
}

\author{
Hasan Çağlar Başol a * iD , Galip Kartal ${ }^{\text {b }}$ iD \\ ${ }^{a}$ Selçuk University, Konya, 42130, Turkey \\ ${ }^{b}$ Necmettin Erbakan University, Konya, 42090, Turkey
}

\section{APA Citation:}

Başol, H. Ç., \& Kartal, G. (2019). The use of micro-level discourse markers in British and American feature-length films: Implications for teaching in EFL contexts. Journal of Language and Linguistic Studies, 15(1), 276-290.

Submission Date:.05/10/2018

Acceptance Date:23/01/2019

\begin{abstract}
Discourse markers (DMs) are significant for fluent speech. Furthermore, they are essential elements of language for conversation organisation, reciprocal relation of interlocutors, productive speaking and comprehension. Although they have critical functions for pragmatic development, they are neglected in language teaching either because of the belief that they are challenging to teach or as a result of the focus on grammatical competence in language teaching. This study examined the use and functions of micro-level DMs in British and American featurelength films, and it provided implications for using feature-lengths films as a means for authentic language input in explicit or implicit teaching of DMs. The scripts of four films (two British and two American) were analysed using the AntConc Concordance program. The results showed that there is not a significant difference between British and American films regarding the frequency of DMs well, like, and you know. On the other hand, it was found that $o h$ was used more frequently in British films than American films. The functional analysis of the DMs showed that both British and American feature-length films represent the use of English DMs in native discourse. Therefore, the study concludes that the films could be used for teaching and learning of DMs in foreign language classrooms. The results were discussed with pedagogical implications.
\end{abstract}

(C) 2019 JLLS and the Authors - Published by JLLS.

Keywords: Discourse markers; films; frequency; pedagogical implications; teaching

\section{Introduction}

Language is not merely a tool to communicate but a system that transfers ideas, feelings, emotions, beliefs and cultures to others. Humans use many devices of languages, which make this transfer of thoughts and experiences smoother, more effective and appropriate even when interlocutors have difficulties, hesitations, or pauses during their interactions. One of those devices is discourse markers (DMs), and they are commonly used by native speakers of a language either in spoken or written discourse to deliver the message effectively. DMs might help developing an ongoing and intimate relationship with people (Quirk et al. 1985 as cited in As1k \& Cephe, 2013), enhancing spoken production (Müller, 2005; Uicheng \& Crabtree, 2018), increasing text comprehension (Sadeghi \&

\footnotetext{
${ }^{*}$ Corresponding author. Tel.: +90 332-223-1529

E-mail address: caglar.basol@ selcuk.edu.tr
} 
Heideryan, 2012), empowering lecture comprehension (Rahimi \& Riasati, 2012; Sadeghi \& Heideryan, 2012) and enhancing the quality of written essays (Dastjerdi \& Shirzad, 2010). As for non-native speakers learning English as a foreign language, DMs might help them to "gain nativeness in the spoken or written discourse", making them feel comfortable in using the language (As1k \& Cephe, 2013, p. 145).

It is a fact that while teaching certain language forms and protocols, authentic items are more productive than the materials artificially designed for teaching purposes (Johns, 1994). DMs are among the top ten words used in everyday conversation by native speakers (Allwood, 1996). Therefore, to understand and acquire their function, it might be better to teach them with authentic materials. Studies support the view that the acquisition of DMs can be successful when they are taught with authentic materials instead of the texts sounding artificial (Flowerdew \& Tauroza, 1995; Jones \& Carter, 2013; Rahimi \& Riasati, 2012). Unfortunately, in contexts where English is used as a foreign language, exposure to authentic linguistic items is extremely limited in daily life.

What is more, it is generally observed that the teaching of DMs is ignored and neglected, and not covered extensively in teaching materials (Zorluel-Özer \& Okan, 2018). When we observe this fact with the reality that DMs have essential functions in written and spoken discourse, a crucial question comes into the mind: How can language teachers help EFL learners to reach authentic use of DMs in and out of the classroom? In this study, we tried to show that feature-length films are among the ways to do it.

Various studies have investigated the use of DMs or pragmatic markers by non-native speakers of English (Aijmer, 2011; Asık \& Cephe, 2013; Aysu, 2017; Fung \& Carter, 2007; Hellermann \& Vergun, 2007; Liao, 2009). The variables which might affect the use of DMs have also been investigated mostly in some of these studies. The results revealed significant differences between native and non-native speakers' use of DMs (Fung \& Carter, 2007; Lee, 2010; Liao, 2009), especially in the use of individual functions of DMs (Liao, 2009).

Although various research focused on the use of DMs by non-native speakers of English and compared the usage among native and non-native speakers, very few of them investigated how DMs are used in lingual and cultural products as potential language teaching materials. Therefore, this study was designed to investigate the use and functions of DMs in British and American feature-length films by comparing the functions of them in two widespread accents of English. This kind of research is significant for material development and teaching of DMs. Besides, investigating the differences between British and American English might have some implications for understanding whether it is appropriate to rely on the usage in the films as a standard sample of DMs in English. The study might also help to evaluate the extent to which watching films facilitates learning of DMs.

\subsection{Literature review}

Discourse markers (DMs) are studied under many labels like discourse markers, discourse connectives, discourse operators, pragmatic connectives, sentence connectives, and cue phrases (Fraser, 1999). Similarly, there is no accord on the definition of DMs, and many definitions have been provided so far. They are lexical items that are optional and multifunctional, and they do not belong to a specific grammatical class (Jones \& Carter, 2013, p. 40). Considering them as cohesive devices, Schifrin (1987) defines DMs as "sequentially dependent elements which bracket units of talk" (p. 31). According to Buysse (2012), DMs "connect an utterance to its co-text and/or the context" (p. 1764). Fraser (1999) defines DMs "as a class of lexical expressions drawn primarily from the syntactic classes of conjunctions, adverbs, and prepositional phrases" (p. 931). In a similar vein, Fung and Carter (2007) define DMs as "intra-sentential and supra-sentential linguistic units which fulfil a largely nonpropositional and connective function at the level of discourse" (p. 411). Accordingly, they have the 
function of signalling a "transition", "relation" and "interactive relationship" in a conversation, in between preceding and subsequent context, and among the speaker, hearer and the message (Fung \& Carter, 2007).

Scholars have different ideas to determine criteria to consider a lexical item or utterance as a DM. For instance, Schiffrin (1987) mentions about eleven English DMs. These are oh, well, and, but, or, so, because, now, then, I mean, y'know.

Green (2006) categorises DMs as attitudinal (e.g. well, uh, like, gosh, oh, OK, I mean, and you know) and structural (e.g. now, $O K$, and, but). While the former is mostly about the feelings of the addresser and the addressee, the latter indicates a structural boundary. According to Schiffrin (1987, p. 314), there are some requisites in order to name a linguistic feature as a DM:

- It has to be syntactically detachable from a sentence.

- It has to be commonly used in the initial position of an utterance.

- It has to have a range of prosodic contours.

- It has to be able to operate at both local and global levels of discourse.

- It has to be able to operate on different planes of discourse.

Schiffrin (1987) mentions five functions of DMs. These are 1) Exchange: Indexing shifts at the level of the turn, 2) Action: Marking moves designed to accomplish an action, 3) Ideation: Organizing and marking relations between ideas, 4) Participation: Marking shifts in the roles of participants, and 5) Information Management: Checking on the flow of information.

As for Fung and Carter (2007), one important criterion to consider a lexical item as a DM is the position of the utterance in the speech to perform various functions such as marking "boundaries of talk, topic initiation, topic closure and attention seeking." Another criterion is the independent prosody which might be marked by "prosodic clues" such as "pauses, phonological reductions, and separate tone units." The other one is the multigrammaticality of the DMs; they are part of various grammatical forms such as "conjunctions, prepositional phrases, adverbs, minor clauses, interjections, response words, and metaexpressions." Indexicality is another criterion that "signal[s] the relation of an utterance to the preceding context and to assign the discourse units a coherent link." This link could be "conceptually empty (well, OK, hey, oh), partly conceptual (so-with the semantic meaning 'cause') and conceptually rich (I guess, I think, first, second, obviously, frankly)." The last criterion is optionality. Optionality refers to the interlocutors' preferences to use or not to use DMs in speech. They can be omitted from a discourse without any syntactic or semantic effect; however if done so, listeners will be left without any clue for in what way to interpret the proposition that the other speaker offers (pp. 412-414).

Another well-defined categorisation of DMs is provided by Chaudron and Richards (1986 cited in Uicheng \& Crabtree, 2018) for lectures. They portray a detailed categorisation for DMs and accordingly group them as the baseline, micro, macro and micro-micro DMs. In the baseline level, there are no DMs used in discourse and every word/utterance is needed to deduce the meaning. In the micro level, various markers such as then, and, now, after, at that time, because, so, but, actually, you see, unbelievably, of course, well, ok, alright? are used in discourse. Macro-level DMs include expression such as to begin with, let's go back to the beginning, what I am going to talk about today etc., which are generally used as an opening, summarising or closing statement in a lecture or speech. Micro-macro level includes the use of both types of markers together.

In this study, based on the scholars and studies mentioned above, we focused on DMs in micro level and limited the analysis with well, like, you know and oh since they are the most frequently used DMs (Schourup, 1985). Additionally, extensive literature is available on the characteristics of these DMs (Polat, 2011). 


\subsection{Previous research on discourse markers}

Numerous studies compared the use of DMs by native and non-native speakers of English (eg., Aysu, 2017; House, 2009). With the recognition of the significance of communicative competence, the number of studies about non-native speakers showed a notable increase over the last decades. Many of these studies found that native and non-native speakers show differences in the use of DMs (Fung \& Carter, 2007; House, 2009, Müller, 2004). House (2009), for instance, found that while native speakers of English mostly use you know for receding into the background, the non-native speakers use it to create coherence in the talk. Müller (2004) compared German and American native speakers of English for the use of DMs. She found differences between the two groups of speakers. Lam (2009) conducted a study in order to compare the use of DMs in Hong Kong Corpus of Spoken English and a textbook database. The results were discussed for the frequency of occurrence, position and discourse function of the DM. In all three areas, significant differences were observed. These reports about the differences between native and non-native speakers of English on the use of DMs lead us to focus on the significance of teaching of DMs to non-native speakers.

Some previous studies investigated the relationship between DM usage and English proficiency as well. Martinez (2009), who focused on writing comprehension, found a significant positive correlation between DM usage and writing comprehension. Furthermore, Escalera (2009) investigated the effects of gender on DM usage. After gathering data from naturalistic observation of child-peer conversation, Escalera observed gender differences in young children's use of DMs as the previous research findings suggested.

Some research papers focused on only one or two DMs and tried to detect every possible function of them. Some of the DMs which were analyzed in depth are: so (Bolden, 2009; Buysse, 2012), well (Aijmer, 2011; Lam, 2009; Schourup, 2001), well and but (Norrick, 2001), I don't know and I dunno (Grant, 2010), just (Grant, 2011), and no (Lee-Goldman, 2011). Part of the previous research found that genre might have an impact on the function of a DM. Norrick (2001), for instance, found the functions of well and but similar in storytelling while it showed the difference in the conversation. This distinction leads us to investigate DMs and their functions in different discourses. In other words, DMs are sensitive to the discourse, which makes them difficult to group into a single category.

Besides spoken data, some research was conducted to investigate the usage of DMs in written materials. Gholami, Mosalli and Nikou (2012) examined the development of DMs in the abstracts of 120 soft and hard sciences articles of English for Specific Purposes. The researchers studied psychology and tourism as soft sciences and engineering and physics as hard sciences. In each science, 30 articles were analysed. The results yielded significant differences between the type of the article and the DMs regarding both frequency and function.

\subsection{Films and language learning}

Webb and Rogers (2009, p. 412) indicate that "materials which provide visual and aural input such as films may be conducive to incidental vocabulary learning." In a similar vein, Webb (2010) states watching films may provide an opportunity for exposure to unknown words. Recently, Clarry Sada (2016) recommended the use of sitcoms for the teaching of DMs since they provide natural language input in which students will be able to see the DMs in context. Results of the studies above also portray how authenticity is crucial for the acquisition of DMs. The authenticity of the materials is presented to be crucial to raise awareness among students on DMs. Hence, feature-length films are thought to be alternative materials to teach DMs in this study. 


\subsection{Research questions}

Based on the hypothesis that feature-length films are appropriate sources as natural input for DMs, this study aims at determining how certain micro-level DMs are used in British and American films. By doing this, it also focused on how films can be used to teach DMs in EFL contexts as sources of authentic materials. The following research questions were constituted in order to fulfil these aims.

1. What is the difference between British and American films in terms of the number of used micro-level discourse markers of oh, well, like, and you know?

2. How are micro-level discourse markers of oh, well, like and you know presented in the films?

Based on the results of the RQ1 and RQ2 and the scholarship of the previous research, we discussed how feature-length films might be considered appropriate to teach DMs.

\section{Method}

\subsection{Research design and instruments}

A film is considered as feature-length when it is typically 90 or more minutes long (Cambridge Dictionary Online, n.d.). In this study, we used two British and two American feature-length films.

Table 1. Information about the films used in the study

\begin{tabular}{cccccc}
\hline Film & Country & Year & Genre & Director & $\begin{array}{c}\text { Total Running } \\
\text { Words }\end{array}$ \\
\hline Bridget Jones Diary 2 & British & 2004 & $\begin{array}{c}\text { Comedy, } \\
\text { Romance }\end{array}$ & Beeban Kidron & 10.256 \\
$\begin{array}{c}\text { The Railway Children } \\
\text { Million Dollar Baby }\end{array}$ & British & 1970 & Drama & Lionel Jeffries & 9.674 \\
$\begin{array}{c}\text { Mr. Smith Goes to } \\
\text { Washington }\end{array}$ & American & 1939 & Drama, Classic & Frank Capra & 10.325 \\
\hline
\end{tabular}

Table 1 shows the films analysed in this study based on their country, production year, genre, and director, and total running words. As could be seen from the table the oldest film dates back to 1939 while the newest one dates back to 2004. Hence, they portray a good example of the function of DMs in an extensive discourse in a wide time-span.

As we have already mentioned before, both Schiffrin (1987) and other scholars defined various micro-level DMs such as oh, well, and, but, or, so, because, now, then, I mean, and y'know. However, we focused on oh, well, like and you know in this study since they are the most common (Schourup, 1985) and ambiguous lexical items that can serve as DMs. Polat (2011) also highlighted three of these DMs (like, well, and you know) as the most frequently analysed DMs in foreign language settings. Thus, we limited ourselves only with the analysis of oh, well, like and you know.

\subsection{Data collection and analysis procedure}

The data consists of four feature-length films -two American and two British. The scripts of the films were scanned for every possible DM instance. Schiffrin's (1987, p. 314) five criteria were utilized 
while determining the DMs in the four movie scripts. These criteria are a word; "1) has to be syntactically detachable from a sentence, 2) has to be commonly used in initial position of an utterance, 3 ) has to have a range of prosodic contours, 4) has to be able to operate at both local and global levels of discourse, and 5) has to be able to operate on different planes of discourse" to be considered as a DM.

AntConc (Anthony, 2011) was used to find frequencies for the DMs. As like and well could also play many other roles like a verb and adverb, the number of the DMs was counted manually.

\section{Findings}

3.1. Findings related to Research Question 1: What is the difference between British and American films in terms of the number of used micro-level discourse markers of oh, well, like, and you know?

This research question was constituted to compare the frequency and functions of DMs in British and American feature-length films. Table 2 shows the total number of micro-level DMs in the films.

Table 2. Discourse marker occurrences of oh, well, like, you know in the film scripts

\begin{tabular}{lccccc}
\hline Film & oh & well & like & you know & Total \\
\hline Bridget Jones Diary 2 & $175 / 175$ & $46 / 41$ & $31 / 4$ & $18 / 14$ & $270 / 234$ \\
The Railway Children & $79 / 79$ & $46 / 42$ & $44 / 5$ & $10 / 7$ & $179 / 133$ \\
Million Dollar Baby & $20 / 20$ & $57 / 54$ & $6 / 3$ & $19 / 8$ & $102 / 85$ \\
Mr.Smith Goes to Washington & $20 / 20$ & $21 / 11$ & $70 / 8$ & $12 / 5$ & $123 / 44$ \\
Total & & & & & \\
& $294 / 294$ & $170 / 148$ & $151 / 20$ & $59 / 34$ & $674 / 496$ \\
\hline
\end{tabular}

Table 2 shows how many times the studied lexical items are used as micro-level DMs in total usage. As can be seen in the table, oh, well, and you know are mainly used as DMs. While oh is used as a DM all the time, well, like, and you know also have other functions that are not the concern of the study. For instance, like is used as a DM for 20 times out of 151 occurrences. Other usages of the like include verbs or prepositions. In addition, oh is significantly used more often in British films. The other DMs do not show any tendency concerning the difference in frequency. However, the frequency of well in the movie Mr. Smith Goes to Washington is much lesser than the others. The distribution of these lexical items as a DM or not is illustrated in figure 1.

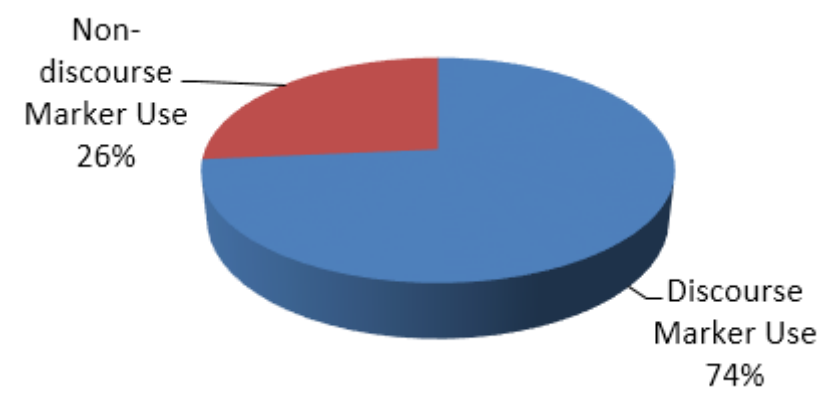

Figure 1. Discourse marker and non-discourse marker use of oh, well, like, and you know in the films. 
As can be seen in Figure 1, the lexical items analysed in this study are mostly used as DMs (74\%), and they also perform other functions that cannot be categorized as DMs (\%26).

\subsection{Findings related to Research Question 2: How are micro-level discourse markers of oh, well, like and you know presented in the films?}

The aim of the second research question was examining the DMs oh, well, like, and you know regarding DM functions. In other words, a comparison between the literature and the data of this research was conducted. The functions of the DMs are provided under each DM below.

$\mathrm{Oh}$

Although Fraser (1988) considers $o h$ as an interjection and subordinating conjunction rather than a DM, Green (2006) shows that $o h$ is an attitudinal DM. Contrary to the other DMs investigated in this study, every occurrence of $o h$ was a DM. The functions of $o h$ as a DM are analysed in the light of Schiffrin's (1987) categorisation. According to him, the two functions of $o h$ include information display and evaluation. More specifically it shows a change in the speaker's knowledge, awareness, or attention. Besides, Trester (2009, p. 149) suggests how "oh illustrates a means for stance taking in interaction." The sentences below exemplify change in attention (1), an information display (2), and stance taking (3).

1. "Where was l?"

"Oh, yes... Mark Darcy.” (Bridget Jones Diary)

2. "And you're on speakerphone.

Oh. Right, well..." (Bridget Jones Diary)

3. "Good evening, ma'am."

"Good evening, Sally."

"Oh, it's so cold!"

"Let's get to the fire, Peter, come on" (The Railway Children).

Further analysis of oh showed that it is generally used before you know and well in the films. See examples below.

4. a. "I also needed to talk with you about business.

Oh, yeah, well, I just got off the phone with Hogan. We're all set for September." (Million

Dollar Baby)

b. "Is he taking you to the Law Council Dinner?"

"Oh. Well, l'm sure he's just forgotten" (Bridget Jones Diary 2).

All the examples above and many more in the data of this research show that DM functions of $o h$ are adequately portrayed in the feature-length films, which means that the native discourse is represented in the British and American films concerning DM use.

Well

According to Jucker (1993, p. 450), well is used to "signal that the context created by an utterance may not be the most relevant one for the interpretation of the next utterance." Besides including the functions of like and you know, well is also used for contradicting, evaluating, and indirectly replying to previous turns in the discourse (Müller, 2005). The main four functions of well as a DM in the literature are the indication of insufficiency and inadequateness, polite disagreeing, the introduction of a mutual talk, and finally the indication of hesitation (Jucker, 1993; Schourup, 2001).

In addition to the functions above, well is mainly used for filling a pause in the flow of speech in the films. In example 1, well is used for insufficiency and inadequateness. Examples in 2 are exemplifying 
the polite disagreeing function of well. Example 3 reflects an introduction to a mutual talk, and example 4 represents hesitation.

1. "And nothing in the world can spoil it."

"Well, almost nothing." (Bridget Jones Diary 2)

2. a. "Bridget, you must want to hear those ding-dong bells."

"Well, we're certainly not thinking about that yet. Are we, Bridget?" (Bridget Jones Diary 2)

b. "I gotta agree, I am embarrassing myself. -Yeah."

"Well, I can't just lend it to anybody, you know". (Million Dollar Baby)

3. "Well, why don't we wave anyway?

"Three waves won't matter."

"We won't miss them. (The Railway Children)

4. "I also needed to talk with you about business."

"Oh, yeah, well, I just got off the phone with Hogan. We're all set for September." (Million Dollar Baby)

The movie scripts constitute data which cover almost all DM functions of well in the literature. Well is also the second most frequent DM in this study's data. It is consistent with the findings of Fuller's (2003) study, which showed that well is one of the most frequent DM in the native discourse. Furthermore, the DM functions of well are consistent with the examples of Popescu-Bellis and Zufferey (2011).

\section{Like}

Besides being a DM, like may be an adverb, a noun, a verb, an adjective, or a preposition. As a DM, like is used for approximating, exemplifying, and hedging (Jucker \& Smith, 1998). In this paper, both stance adverbial and DM was included in the analysis of the frequency of like. The movie scripts in this study provide an example of all functions of like as a DM. Just like Jucker and Smith suggest, in films like is used for hedging (1), exemplifying (2), and approximating (3).

1. a. "Because she-- Like, you, you could fight to him" (Bridget Jones Diary).

b. "But if I throw a party man like..." (Mr.Smith Goes to Washington).

2. a. "You see, there's the high-fliers, like Annabel and Mark Darcy" (Bridget Jones Diary).

b. "And I saw myself breathing. Like, my body was going up and down" (Million Dollar Baby).

c. "Don't just stand there like a... Wait a minute" (Mr.Smith Goes to Washington).

3. "Like a great big garden-squirt" (The Railway Children).

The three DM functions of like suggested by Jucker and Smith (1998) are used in the films, which means that native discourse of DM like is adequately represented in the films.

\section{You know}

According to Müller (2005), among DMs, you know is "one of the most versatile and notoriously difficult to describe" (p. 147). You know is considered as a DM when it is not syntactically necessary to an utterance in the movie scripts. Hence the occurrences of you know in sentences like "Do you know, l never really understood why you wanted to go out with me" (Bridget Jones Diary 2) and "You can't do it, you know that" (Million Dollar Baby) were excluded.

You know is heavily used in the native speaker corpora (Fung \& Carter, 2007). House (2009) observed the use of you know as gap filler too. There were some examples to this function in the films 
as well. According to Muller (2005), some of the DM function of you know are marking lexical or content search, false start and repair, approximation, and introducing an explanation. Lexical or content search and approximation functions were embarked to "you know" in the data of this research. However, there wasn't an example to false start and repair function. The conversation in example 1 shows lexical or content search functions of you know. The gap filling (House, 2009) function of you know can be seen in example 2 .

1. "It really wasn't my fault."

"It's a fizzy drink, you know, it just..." (Bridget Jones Diary 2)

2. "Hey, you know, I got nothing against ......"

"Well, that's nice to hear." (Million Dollar Baby)

The overall use of you know as a DM was the least frequent one among the four micro DMs investigated in this study.

\section{Discussion}

We have already mentioned that DMs have essential functions in written and spoken discourse. They are also indicators of the pragmatic development. Although they have such an important function, they are not included in the course materials or in the curriculum specifically to be taught, and some material designers prefer to include them in conversations to sound authentic. While macro-level DMs such as however, on the other hand, what is more are taught in writing classes for the organisation of the written texts, they are rarely taught for speaking (Uicheng \& Crabtree, 2018, p. 28). Micro-level DMs such as oh, well, like, you know are also rarely taught in speaking and writing. As we have mentioned already, one reason for this is their difficulty in teaching. As De Klerk (2005) suggests, their "lack of semantic definition" and "syntactic function" might make their explicit teaching difficult (p. 275). However, another reason might be the belief that grammatical development precedes pragmatic development, so DMs might be omitted from the EFL curriculum since they are not part of the grammar [one might wish to check Kasper (2001) for a discussion on grammar precedes pragmatics and vice versa]. Another reason might also be related to how language teachers and program developers approach DMs. As mentioned by Jones and Carter (2013), DMs, with the cultural identity they represent, might be considered as part of the native corpus, so that they are not included in the contexts where English is taught as a foreign language.

The truth is teaching DMs is not hard, and various explicit and implicit teaching methods and techniques including the feature-length films could be adapted for teaching. What is more, grammar and pragmatics do not necessarily precede one another, and they might develop together from the beginning. They are not necessarily sequential, and high level of grammatical competence might not always guarantee a high level of pragmatic competence (Bardovi-Harlig, 1999) and vice versa. Additionally, DMs have a discoursal function to "enhance fluent and naturalistic conversational skills, to help avoid misunderstanding in communication, and, essentially, to provide learners with a sense of security in L2" (Fung \& Carter, 2007, p. 433). What is more, DMs do not represent a cultural identity in the way that slangs, idioms and colloquial language do. Therefore, they might be valuable to acquire for practical, productive use of English (Jones \& Carter, 2013, p. 38) also in foreign language contexts. Thus, the teaching of DMs as an effort to develop pragmatic competence might help students to engage in successful spoken interactions with others, and understand and acknowledge the appropriateness of spoken interactions. They may also decode the direct or implied meanings given by interlocutors effectively and appropriately. Then, the question we need to focus on is not whether to teach DMs but whether we can rely on feature-length films as appropriate materials for teaching. 
Findings related to the research questions 1 and 2 support the view that feature-length films could be used as appropriate materials for teaching DMs, and there are many ways to apply with. First, the films we analysed for this study portrayed a varied use of micro-level DMs. Those usages comply with the functions that were defined in the previous studies. Thus, they might be considered as an appropriate natural language source that can be applied in the classroom for teaching DMs. It could be seen from the examples given here that, although the discourse analysed in the study takes place in a scenario, they sound natural and authentic when evaluated together with the context presented in the videos. Hence, those scenes could be used to present, illustrate or analyse the DMs to be taught depending on the level, skills, and attitudes of the students. It is true that there are various techniques to use while teaching DMs and explicit teaching might yield successful results (Clarry Sada, 2016; Kasper, 2001; Sadaghi \& Heideryan, 2012), since students might not be able to recognise those DMs on their own. However, a combination of implicit and explicit techniques might also be applied since every student might have a different learning style and preference (Rahimi \& Riasati, 2012).

For a traditional role-play activity, authentic scenes including DMs might be used and practised with the students. Those scenes might also be an alternative to the native-talk for students primarily in the contexts where students do not have access to native teacher-talk. The scenes might be used to present, practice and produce (P-P-P model) newly learned DMs. Although this technique is criticised as being superficially attractive with no long-term acquisition (Carless, 2009, pp. 63-64.), it can be used as an initial step with less proficient students to increase their awareness on the use and functions of the DMs while working on the authentic materials like movies. Nevertheless, a task-based approach to teaching DMs (although still explicit) might lead to better retention of the newly acquired structures by learners as proved by Alraddadi (2016) with Saudi EFL learners.

"Noticing hypothesis" (Schmidt, 1995) might be applied along with a metapragmatic approach (Fung \& Carter, 2007) with more advanced students. Bringing samples scenes to the class, teachers might encourage students to notice the DMs used in the target language context. By analysing recurrent patterns of DMs, students might figure out the rules and principles regarding semantic, syntactic and communicative functions of the DMs. In this way, the input through the scenes will become an intake.

An approach in which students would compare the discoursal situation in the movie scenes to a similar context in their L1 can be applied while teaching DMs based on the idea of two-dimensional modal. As referred by Kasper (2001), two-dimensional modal claims that adult learners of L2 heavily rely on universal or L1 based pragmatic knowledge to develop their L2 pragmatic knowledge. For instance, L2 learners may rely on the concept of politeness in their L1 to decide which modality to use in their spoken interaction to sound polite in L2. Similarly, through those scenes, students might learn how to use those DMs in certain social situations. Hypothetically, L2 learners might associate those DMs with their L1 counterparts or vice versa and might try to use them in their spoken interactions. It might also contribute to their socio-pragmatic competence.

To sum up this discussion, we need to state that feature-length films seem to be appropriate materials to teach DMs implicitly and explicitly, and there are many ways to use them depending on the theory, the method and the technique that teachers apply. It should be kept in mind that DMs are part of the pragmatic ability; the theories and the empirical perspectives for the acquisition of it are varied. As Kasper (2001) suggests, teachers can choose a principled approach for which theory, method and techniques to apply, and they should not do it thinking that any approach would fit in the classroom. 


\section{Conclusion}

As stated by Fung and Carter (2007), the pedagogical significance of DMs in EFL settings is not studied satisfactorily. Moving from this fact, we asked whether the films could be used to teach DMs in EFL classrooms, this study was designed to investigate the descriptions and presentations of DMs in feature-length British and American films. More specifically, this study examined whether these films reflect the contemporary use of micro-level DMs. Additionally, a comparison between British and American films concerning frequencies and presentations of the DMs was conducted.

The results of the current study showed that well is the most prevalent DM in all four films. This study yielded very similar patterns of DM use to the native speaker discourse. All these findings imply that both British and American films might be used as representative of DM usage in native discourse.

Although we have implications for the use of feature-length films for teaching DMs explicitly, future studies may consider using feature-length films in actual classroom teaching to test whether those could be used successfully or not. Following studies might also consider using feature-length films as sources of teaching English DMs, to make those visual materials more accessible to EFL learners, who have limited access to authentic target language outside of the classroom.

This research may serve as a preliminary study of investigating the effects of films on the teaching and learning of DMs by EFL learners. The functions of the DMs in the films we analysed were appropriate to teach the native speakers' usage. By selecting appropriate British or American films, language teachers may develop materials to teach English DMs.

Note: The first draft of this paper was presented at the 6. International Conference on Intercultural Pragmatics \& Communication, Msida-MALTA.

\section{References}

Aijmer, K. (2011). Well I'm not sure I think The use of well by non-native speakers. International Journal of Corpus Linguistics, 16(2), 231-254.

Alraddadi, B. M. (2016). The effect of teaching structural discourse markers in an ELF classroom setting. English Language Teaching, 9(7), 16-31.

Allwood, J. (1996). Talspraksfrekvenser. Gothenburg Papers in Theoretical Linguistics S 20. Department of Linguistics, Goteborg University.

Anthony, L. (2011). AntConc (Version 3.2.2) [Computer Software] Waseda University, Tokyo, Japan Available from http://www.antlab.sci.waseda.ac. jp/

Asık, A., \& Cephe, P. T. (2013). Discourse markers and spoken English: Nonnative use in the Turkish ELF Setting. English Language Teaching, 6(12), 144-155.

Aysu, S. (2017). The use of discourse markers in the writing of Turkish students of English as a foreign language: A corpus based study. Journal of Higher Education and Science, 7(1), 132-138.

Bardovi-Harlig, H. (1999). Exploring the interlanguage of interlanguage pragmatics: A research agenda for acquisitional pragmatics. Language Learning, 49(4), 677-713.

Bolden, G. B. (2009). Implementing incipient actions: The discourse marker 'so' in English conversation. Journal of Pragmatics, 41, 974-998. 
Buysse, L. (2012). So as a multifunctional discourse marker in native and learner speech. Journal of Pragmatics, 44, 1764-1782.

Carless, D. (2009). Revisiting the TBLT versus P-P-P debate: voices from Hong Kong. Asian Journal of English Language teaching, 19, 49-66.

Clarry Sada, W. S. (2016). Discourse markers used in short series movie 'Friends' and its relation with English language teaching. Jurnal Pendidikan dan Pembejalaran, 6(6), 1-16.

Dastjerdi, H. V., \& Shirzad, M. (2010). The impact of explicit instruction of metadiscourse markers on ELF learners' writing performance. The Journal of Teaching Language Skills (JTLS), 2(2), 155174.

De Klerk, V. (2005). The use of actually in spoken Xhosa English: a corpus study. World Englishes, 24(3), 275-288.

Escalera, E.A. (2009). Gender differences in children's use of discourse markers: Separate worlds or different contexts? Journal of Pragmatics, 41, 2479-2495.

Feature-length [Def. 1]. (n.d.). In Cambridge Dictionary Online, Retrieved September 5, 2018, from https://dictionary.cambridge.org/tr/sözlük/ingilizce/feature-length

Flowerdew, J., \& Tauroza, D. (1995). The effects of discourse markers on second language lecture comprehension. Studies in Second Language Acquisition, 17, 435-458.

Fraser, B. (1988). Types of English discourse markers. Acta Linguistica Hungarica, 38, 19-33.

Fraser, B. (1999). What are discourse markers? Journal of Pragmatics, 31, 931-952.

Fuller, J. M. (2003). Discourse marker use across speech contexts: a comparison of native and nonnative speaker performance. Multilingua, 22, 185-208.

Fung, L., \& Carter, R. (2007). Discourse markers and spoken English: Native and learner use in pedagogic settings. Applied Linguistics, 28(3), 410-439.

Gholami, J., Mosalli, Z., \& Nikou, S.B. (2012). Lexical complexity and discourse markers in soft and hard science articles. World Applied Sciences Journal, 17(3), 368-374.

Grant, L. E. (2010). A corpus comparison of the use of I don't know by British and New Zealand speakers. Journal of Pragmatics, 42, 2282-2296.

Grant, L. E. (2011). The frequency and functions of "just" in British academic spoken English. Journal of English for Academic Purposes, 10, 183-197.

Green, G. M. (2006). Discourse Particles in Natural Language Processing. Retrieved from http://www.linguistics.uiuc.edu/g-green/discourse.pdf

Hellermann, J., \& Vergun, A. (2007). Language which is not taught: The discourse marker use of beginning adult learners of English. Journal of Pragmatics, 39, 157-179.

House, J. (2009). Subjectivity in English as Lingua Franca discourse: The case of you know. Intercultural Pragmatics, 2, 171-193.

Johns, T. (1994). From Printout to Handout: Grammar and vocabulary teaching in the context of datadriven learning. In Terense Odlin (Ed.) Perspectives on pedagogical grammar. Cambridge: Cambridge University Press.

Jones, C., \& Carter, R. (2013). Teaching spoken discourse markers explicitly: A comparison of III and PPP. International Journal of English Studies, 14(1), 37-54. 
Jucker, A. (1993). The discourse marker 'well': A relevance-theoretical account. Journal of Pragmatics, 19, 435-452.

Jucker, A., \& Smith, S. (1998). And people just you know like 'wow': discourse markers as negotiating strategies. In: Jucker, A., Ziv, Y. (Eds.), Discourse Markers: Descriptions and Theory (pp. 171-202). John Benjamins, Philadelphia.

Kasper, G. (2001). Four perspectives on L2 pragmatic development. Applied Linguistics, 22(4). 502530.

Lam, P. W. Y. (2009). Discourse particles in corpus data and textbooks: The Case of Well. Applied Linguistics, 31(2), 260-281.

Lee, M. L. (2010). Interlanguage spoken discourse - exploratory study in discourse markers. Journal of Far East University General Education, 4, 165-184.

Lee-Goldman, R. (2011). No as a discourse marker. Journal of Pragmatics, 43, 2627 - 2649.

Liao, S. (2009). "Variation in the use of discourse markers by Chinese teaching assistants in the US". Journal of Pragmatics, 41, 1313-1328.

Martínez, A. (2009). Empirical Study of the Effects of Discourse Markers on the Reading Comprehension of Spanish Students of English as a Foreign Language. International Journal of English Studies, 19-43.

Müller, S. (2004). Well you know that type of person: Functions of well in the speech of American and German students. Journal of Pragmatics, 36, 1157-82.

Müller, S. (2005). Discourse markers in native and non-native English discourse. John Benjamins, Philadelphia.

Norrick, N. R. (2001). Discourse markers in oral narrative. Journal of Pragmatics, 33, 849-878.

Polat, B. (2011). Investigating acquisition of discourse markers through a developmental learner corpus. Journal of Pragmatics, 43, 3745-3756.

Popescu-Belis, A., \& Zufferey, S. (2011). Automatic identification of discourse markers in dialogues: An in-depth study of like and well. Computer Speech and Language, 25, 499-518.

Rahimi, F., \& Riasati, M. J. (2012). The effect of explicit instruction of discourse markers on the quality of oral output. International Journal of Applied Linguistics \& English Literature, 1(1), 7081.

Sadeghi, B., \& Heideryan H. (2012). The effect of teaching pragmatic discourse markers on EFL learners' listening comprehension. English Linguistics Research, 1(2), 165-176.

Schiffrin, D. (1987). Discourse markers. Cambridge: Cambridge University Press.

Schmidt, R. (1995). Consciousness and foreign language learning: A tutorial on the role of attention and awareness in learning. In: R. Schmidt (ed.). Attention and Awareness in Foreign Language Learning. Honolulu: University of Hawaii Second Language Teaching and Curriculum Center. pp.-1-63.

Schourup, L. C. (1985). Common Discourse Particles in English Conversations: 'Like', 'Well', 'Y'know'. Garland, New York, NY/London, UK.

Schourup, L.C. (2001). Rethinking 'well'. Journal of Pragmatics, 33, 1025-1060. 
Trester, A.M. (2009). Discourse marker 'oh' as a means for realizing the identity potential of constructed dialogue in interaction. Journal of Sociolinguistics, 13(2),147-168.

Uicheng, K., \& Crabtree, M. (2018). Micro discourse markers in TED Talks: How ideas are signaled to listeners. PASAA, 55, 1-31.

Webb, S. (2010). A corpus driven study of the potential for vocabulary learning through watching films. International Journal of Corpus Linguistics, 15, 497-519.

Webb, S., \& Rodgers, H. (2009). The lexical coverage of films. Applied Linguistics, 30, 407-427.

Zorluel-Özer, H. \& Okan, Z. (2018). Discourse markers in EFL classroom: A Corpus-driven research. Journal of Language and Linguistics Studies, 14(1). 50-66.

\section{İngiliz ve Amerikan uzun metrajlı filmlerinde mikro düzey söylem belirleyicilerinin kullanımı: Yabancı Dil Olarak İngilizce bağlamında öğretim için çıkarımlar}

\section{$\ddot{O} z$}

Akıcı bir konuşma için söylem belirleyicileri önemlidir. Ayrıca, bunlar konuşma örgütü için dilin önemli unsurları, muhataplar arasında karşılıklı ilişki kurma ve üretken konuşma ve anlama için önem arz etmektedir. Her ne kadar pragmatik gelişim için çok önemli işlevleri olsa da, öğretilmelerinin zor olduğuna yönelik inanç ya da dilbilgisi yetkinliğine odaklanılması sebebiyle dil öğretiminde ihmal edilmiş görünmektedirler. Bu çalışma, İngiliz ve Amerikan uzun metrajı filmlerinde mikro düzeydeki söylem belirleyicilerinin kullanım ve işlevlerini incelemekte ve bu filmlerin otantik dil kaynağı olarak söylem belirleyicilerinin doğrudan veya örtülü öğretimde kullanılmasına yönelik çıkarımlar sunmaktadır. Dört filmin yazılı metinleri (iki İngiliz ve iki Amerikan) AntConc Concordance programı kullanılarak analiz edilmiştir. Sonuçlar, İngiliz ve Amerikan filmleri arasında well, like, ve you know söylem belirleyicilerinin kullanım sıklı̆̆ bakımından anlamlı bir fark olmadığını göstermiştir. Öte yandan, İngiliz filmlerinde Amerikan filmlerine göre oh söylem belirleyicisinin daha sık kullanıldığı görülmüştür. Söylem belirleyicilerinin fonksiyonel analizi, hem İngiliz hem de Amerikan uzun metrajlı filmlerin İngilizcenin yerli söylemini temsil ettiğini göstermiştir. $\mathrm{Bu}$ nedenle, çalışma, filmlerin yabancı dil eğitiminde söylem belirleyicilerinin öğretimi ve öğrenimi için kullanılabileceği sonucuna varmıştır. Sonuçlar pedagojik çıkarımlar açısından tartışılmıştır.

Anahtar sözcükler: söylem belirleyicileri; filmler; sıklık; öğretimsel çıkarımlar; öğretim

\section{AUTHOR BIODATA}

Dr. Hasan Çağlar Başol is a researcher in English Language and Literature Department at Selcuk University, Konya, Turkey. His current research interests include intercultural communication, second language teacher education, and language policy. 
Dr. Galip Kartal is an Assistant Professor in the English Language Teaching Department at Necmettin Erbakan University, Konya, Turkey. His research focuses on learner corpora, the design and applications of innovative language learning \& teaching techniques, and second language teacher education. 